\title{
Performance of pineapple slips inoculated with diazotrophic phosphate-solubilizing bacteria and rock phosphate
}

\author{
Lílian Estrela Borges Baldotto ${ }^{1}$, Marihus Altoé Baldotto ${ }^{2}$, Fábio Lopes Olivares ${ }^{3}$ Adriane Nunes de Souza ${ }^{4}$
}

\begin{abstract}
Besides fixing $\mathrm{N}_{2}$, some diazotrophic bacteria or diazotrophs, also synthesize organic acids and are able to solubilize rock phosphates, increasing the availability of $\mathrm{P}$ for plants. The application of these bacteria to pineapple leaf axils in combination with rock phosphate could increase $\mathrm{N}$ and $\mathrm{P}$ availability for the crop, due to the bacterial activity of biological nitrogen fixation and phosphate solubilization. The objectives of this study were: (i) to select and characterize diazotrophs able to solubilize phosphates in vitro and (ii) evaluate the initial performance of the pineapple cultivars Imperial and Pérola in response to inoculation with selected bacteria in combination with rock phosphate. The experiments were conducted at Universidade Estadual do Norte Fluminense Darcy Ribeiro, in 2009. In the treatments with bacteria the leaf contents of N, P and K were higher than those of the controls, followed by an increase in plant growth. These results indicate that the combined application of diazotrophic phosphate-solubilizing bacteria Burkholderia together with Araxá rock phosphate can be used to improve the initial performance of pineapple slips.
\end{abstract}

Key words: Ananas comosus, Burkholderia, plant growth promoting bacteria, inoculant, biofertilizer.

\section{RESUMO}

\section{Desempenho do abacaxizeiro inoculado com bactérias diazotróficas solubilizadoras de fosfatos em conjunto com fosfato de rocha}

Algumas bactérias diazotróficas, além de fixarem $\mathrm{N}_{2}$, também sintetizam ácidos orgânicos, sendo capazes de solubilizar fosfatos de rochas, incrementando os teores de $\mathrm{P}$ para as plantas. A aplicação dessas bactérias, em conjunto com fosfatos naturais, na axila foliar dos abacaxizeiros, poderia incrementar a disponibilidade de $\mathrm{N}$ e de $\mathrm{P}$ para a cultura, em decorrência dos processos de fixação biológica de nitrogênio e de solubilização de fosfatos. Os objetivos deste trabalho foram: (i) selecionar e caracterizar bactérias diazotróficas com potencial de solubilização de fosfatos, em ensaios in vitro e (ii) avaliar o desempenho inicial dos abacaxizeiros 'Imperial' e 'Pérola', em resposta à inoculação das bactérias selecionadas, combinadas com fosfato de rocha. Os experimentos foram realizados na Universidade Estadual do Norte Fluminense Darcy Ribeiro, em 2009. Os tratamentos, contendo bactérias, apresentaram maiores teores foliares de N, P e K, comparados com os dos controles, acompanhados por maior crescimento vegetativo. Esses resultados indicam que a aplicação combinada de bactérias diazotróficas solubilizadoras de fosfatos, do gênero Burkholderia, e fosfato de Araxá pode ser empregada em mudas de abacaxizeiro, visando a melhorar seu desempenho inicial.

Palavras-chave: Ananas comosus, Burkholderia, bactéria promotora de crescimento de plantas, inoculante, biofertilizante.

Received: 06/06/2012; approved: 29/04/2014.

${ }^{1}$ Agronomist Engineer, Doctor of Science. Universidade Federal de Viçosa, Campus Florestal, Rodovia LMG 818, Km 06, 35690-000, Florestal, Minas Gerais, Brazil. lilian.estrela @ufv.br (corresponding author)

${ }^{2}$ Agronomist Engineer, Doctor of Science. Universidade Federal de Viçosa, Campus Florestal, Rodovia LMG 818, Km 06, 35690-000, Florestal, Minas Gerais, Brazil. marihus@ ufv.br ${ }^{3}$ Agronomist Engineer, Doctor of Science. Universidade Estadual do Norte Fluminense Darcy Ribeiro, Avenida Alberto Lamego, 2000, Parque Califórnia, 28013-602, Campos dos Goytacazes, Rio de Janeiro, Brazil. fabioliv@uenf.br

${ }^{4}$ Biologist, Doctor of Science. Universidade Estadual do Norte Fluminense Darcy Ribeiro, Avenida Alberto Lamego, 2000, Parque Califórnia, 28013-602, Campos dos Goytacazes, Rio de Janeiro, Brazil. adrianesouza@gmail.com 


\section{INTRODUCTION}

Endophytic and epiphytic beneficial bacteria that inhabit inner (Halmann et al., 1997) and outer plant parts (Baldotto \& Olivares 2008), respectively, can enhance plant growth by different mechanisms, e.g., plant hormone biosynthesis, biological control, siderophore biosynthesis, induction of systemic resistance in the host plant, antibiotic synthesis, biological nitrogen fixation and phosphate solubilization (Halmann et al., 1997; Rodriguez \& Fraga, 1999).

Tropical soils, which are in an advanced stage of weathering, tend to be electropositive, which results in reduced soil cation exchange capacity and increased retention of anions such as phosphate. Consequently, the availability of $\mathrm{P}$ for plants is restricted, i.e., $\mathrm{P}$ retention in the soil limits the availability for plants. Moreover, there are limitations to the application of nitrogen and soluble phosphate, e.g., high energy costs of production and the need for exploitation of nonrenewable mineral reserves. Several studies involving $\mathrm{N}$-fixing bacteria and phosphate-solubilizing bacteria have been conducted independently. These studies were advanced such as those undertaken in the 1950s (Pikovskaya, 1948; Döbereiner \& Ruschel, 1958), based on bacteria isolation, characterization and subsequent re-introduction into the host plant. Notably, the $\mathrm{N}$-fixing and phosphate-solubilizing bacteria promote plant growth and development. For pineapple diazotrophs were isolated of the genera Burkholderia, Herbaspirillum (Weber et al., 1999), Acetobacter (Tapia-Hernández et al., 2000) and Asaia (Weber et al., 2003), with the actual possibility of using these microorganisms as growth promoters of the host plant (Weber et al., 2010; Baldotto et al., 2010).

The inoculation of the axils of the basal pineapple leaves with diazotrophic phosphate-solubilizing bacteria along with rock phosphate application could result in a greater solubilization of this $\mathrm{P}$ source. Additionally, it is expected that the bacteria inoculated in the basal leaf axils are better protected from harmful effects of ultraviolet radiation and wind, and are in a more moist and nutrient-rich environment, increasing microbial longevity, and consequently the actions of biological nitrogen fixation and phosphate solubilization.

The objectives of this study were: (i) to select and characterize diazotrophs with potential to solubilize phosphates in vitro and (ii) to evaluate plant performance and leaf nutrient accumulation of pineapple 'Imperial' and 'Pérola' in response to application of selected bacteria in combination with rock phosphate.

\section{MATERIAL AND METHODS}

\section{Selection of phosphate-solubilizing diazotrophs in solid medium}

Twenty diazotrophic strains from a bacteria collection of the Laboratory of Cell and Tissue Biology, Universidade Estadual do Norte Fluminense Darcy Ribeiro, were evaluated. The strains were isolated from plants of Ananas comosus (L.) Merrill (Santos, 2008).

Bacteria were grown in liquid DYGS medium (Döbereiner et al., 1995) at $30^{\circ} \mathrm{C}, 100 \mathrm{rpm}$, for $24 \mathrm{~h}$. Aliquots of $2 \mu \mathrm{L}$ of the bacterial solutions were placed on Petri dishes with solid medium (Verma et al., 2001) containing $1.0 \mathrm{~g} \mathrm{~L}^{-1}$ of the P sources: $\mathrm{Ca}_{5}\left(\mathrm{PO}_{4}\right)_{3} \mathrm{OH}, \mathrm{Ca}\left(\mathrm{H}_{2} \mathrm{PO}_{4}\right)_{2}$ and rock phosphate (Araxá rock phosphate: fluorapatite, with $22,7 \% \mathrm{P}_{2} \mathrm{O}_{5}$ total, $4,3 \% \mathrm{P}_{2} \mathrm{O}_{5}$ soluble in citric acid $2 \%$ (1:100), powder particle size), and incubated at $28{ }^{\circ} \mathrm{C}$ for seven days. Phosphate solubilization was measured as the diameter of the translucent halo formed around the Psolubilizing colonies (Baldotto et al., 2010). The ring diameter was measured with a digital caliper and calculated as: ring diameter $(\mathrm{mm})=$ total diameter - colony diameter. Each bacterial strain was tested in three replicates and the test was repeated three times, using Pseudomonas sp (P07) as control (Cattelan et al., 1999).

\section{Quantification of $P$ solubilization, $p H$, and $C F U$ in time in liquid medium}

Of the 20 bacterial isolates, one endophytic strain (UENF 114111) and one epiphytic strain (UENF 117111) were selected, with high P solubilization levels in the above-cited experiment, and analyzed in liquid medium to evaluate the variables: soluble $\mathrm{P}, \mathrm{pH}$ and colony-forming units (CFU) as a function of time. Tests tubes were filled with $50 \mathrm{~mL}$ of bacterial inoculum previously grown in DYGS medium with $10 \mathrm{~mL}$ of liquid culture medium (Verma et al., 2001) containing $\mathrm{Ca}_{5}\left(\mathrm{PO}_{4}\right)_{3} \mathrm{OH}$ and Araxá phosphate as $\mathrm{P}$ sources. The tubes were shaken at $120 \mathrm{rpm}$, at $30^{\circ} \mathrm{C}$. Evaluations were performed 0, 1, 2, 3, 4, 5, days after inoculation. Bacteria were counted $\left(\mathrm{CFU} \mathrm{mL} \mathrm{m}^{-1}\right)$ using the microdrop method. Then the samples were centrifuged at $7500 \mathrm{rpm}$ for $20 \mathrm{~min}$, the $\mathrm{pH}$ was determined in the supernatant and the $\mathrm{P}$ contents were assessed by colorimetry $(725 \mathrm{~nm})$ using molybdate as complexing agent and ascorbic acid as reducer.

The treatments were arranged in a factorial design $[(2 \times 2)+2] \times 6$, consisting of two phosphate-solubilizing bacteria (UENF 114111 and UENF 117111), two P sources $\left(\mathrm{Ca}_{5}\left(\mathrm{PO}_{4}\right)_{3} \mathrm{OH}\right.$ and Araxá rock phosphate) and two control treatments (absence of bacteria), in six evaluations. The experiment was arranged in a completely randomized design with three replications, totaling 108 plots. 


\section{Morphological characterization of the colonies}

The selected bacterial colonies were characterized for color, presence of mucus and morphology (Perin, 2002) on solid JMV and DYGS media (Döbereiner et al., 1995), after seven days of growth in an incubator $\left(28^{\circ} \mathrm{C}\right)$.

\section{Partial sequencing of gene $16 S$ rDNA of the selected bacteria}

The DNA of the selected bacteria was extracted using QIAmp DNA Mini Kit (QIAGEN) according to the manufacturer's instructions. Gene 16S rDNA was amplified by PCR (polymerase chain reaction) using universal primers, 16S forward (FD1 5'AGA GTT TGA TCC TGG CTC AG 3') and 16S reverse (RD1 5' AAG GAG GTG ATC CAG CC 3') (Weisburg et al., 1991). The amplification was performed in a volume of $50 \mu \mathrm{L}$ containing $0.2 \mu \mathrm{M}$ of each primer, $200 \mu \mathrm{M}$ deoxynucleotide triphosphate, Taq buffer provided by the manufacturer, $1.5 \mathrm{mM} \mathrm{MgCl}_{2}, 2.0 \mathrm{U}$ Taq DNA polymerase and $20 \mathrm{ng}$ of template DNA. PCR was initiated with $3 \mathrm{~min}$ denaturation at $94{ }^{\circ} \mathrm{C}$, followed by 30 denaturation cycles at $94{ }^{\circ} \mathrm{C}$ for $1 \mathrm{~min}$, primer annealing at $55^{\circ} \mathrm{C}$ for $30 \mathrm{~s}$, extension at $72{ }^{\circ} \mathrm{C}$ for $2 \mathrm{~min}$, and a final extension for $7 \mathrm{~min}$ in a thermocycler. PCR products were visualized on $1.0 \%$ agarose gels. The sequencing reactions were performed in a total volume of $10 \mu \mathrm{L}$ containing 30-50ng DNA, $5 \mu \mathrm{M}$ of each primer, ABI Prism ${ }^{\circledR}$ Big Dye ${ }^{\mathrm{TM}}$ and $2 \mu \mathrm{L}$ of 2.5 buffer (Tris-HCL $\left.200 \mathrm{mM}, \mathrm{pH} 9.0, \mathrm{MgCl}_{2} 5 \mathrm{mM}\right)$. The reactions were performed under the same conditions as the PCR amplification. The products were precipitated with $75 \%$ isopropanol and washed with $70 \%$ ethanol. Nucleotide sequences were obtained with an ABI Prism 3130 Genetic Analyzer. The sequences were analyzed with the Phred/Phrap/Consed software package (Ewing \& Green, 1998; Ewing et al., 1998; Gordon et al., 1998) and their nucleotide similarity compared with homologous sequences deposited in the global public database GenBank (National Center for Biotechnology Information) (NCBI, 2009) using the BLAST program (Basic Local Alignment Search Tool).

\section{Inoculation treatments of pineapple slips with phosphate-solubilizing diazotrophs together with rock phosphate}

The experimental matrix $[(2 \times 2)+2)]$ consisted of the following factors: two diazotrophic phosphatesolubilizing bacteria (UENF114111 and UENF117111), two pineapple cultivars (Ananas comosus (L.) Merrill, cvs. Imperial and Pérola) and controls (without bacterial inoculation). The greenhouse test was arranged in a completely randomized design with five replicates, totaling 30 experimental units.

\section{Bacterial growth and inoculation}

The inoculum was obtained by growing the bacterium in liquid DYGS at $30^{\circ} \mathrm{C}, 120 \mathrm{rpm}$, for $24 \mathrm{~h}$ and inoculation was performed by immersing the pineapple slip basis in the bacterial medium ( $10 \mathrm{~mL}$ bacterial medium per plant) for $2 \mathrm{~h}$. The controls were immersed in autoclaved liquid DYGS medium. After inoculation, the slips were planted in plastic pots filled with $10 \mathrm{~L}$ of natural soil - B horizon of an Oxisol (EMBRAPA, 1980), from the region of Campos dos Goytacazes - RJ, containing: C (dichromate method in acid medium $)=0.30 \mathrm{~g} \mathrm{~kg}^{-1}, \mathrm{pH}=4.8, \mathrm{P}($ Mehlich-1 $)=6 \mathrm{mg} \mathrm{dm}^{-3}$; $\mathrm{K}^{+}\left(\right.$Mehlich-1) $=5.0 \mathrm{mg} \mathrm{dm}^{-3} ; \mathrm{Ca}^{2+}(1.0 \mathrm{~mol} \mathrm{KCl} \mathrm{extractant}$ $\left.\mathrm{L}^{-1}\right)=0.7 \mathrm{cmol}_{\mathrm{c}} \mathrm{dm}^{-3} ; \mathrm{Mg}^{2+}\left(\mathrm{KCl}\right.$ extractor $\left.1.0 \mathrm{~mol} \mathrm{~L}^{-1}\right)=0.2$ $\mathrm{cmol} \mathrm{dm}_{\mathrm{c}}^{-3}, \mathrm{Al}^{3+}\left(\mathrm{KCl}\right.$ extractant $\left.1.0 \mathrm{~mol} \mathrm{~L}^{-1}\right)=1.3 \mathrm{cmol} \mathrm{dm}^{-3}$, $\mathrm{H}+\mathrm{Al}=4.4 \mathrm{cmol}_{\mathrm{c}} \mathrm{dm}^{-3}, \mathrm{SB}=1.0 \mathrm{cmol}_{\mathrm{c}} \mathrm{dm}^{-3} ; \mathrm{CEC}=5.4 \mathrm{cmol}_{\mathrm{c}}$ $\mathrm{dm}^{-3}$, and $\mathrm{V}=18 \%$. Two grams of Araxá rock phosphate were applied to all plants at the basal leaf axils.

\section{Shoot growth analyses}

The plants were collected, 150 days after planting, to measure the following variables: number of leaves (NL), plant height $(\mathrm{PH})$, measured by the distance from the plant basis to the leaf apex with a measuring tape, stem diameter (SD), measured with a digital caliper; rosette diameter (RD), determined at the greatest linear distance between the apices of opposite leaves with a measuring tape. Samples of leaf D were taken to assess the variables: length of leaf D (LLD), width of leaf D (WLD), fresh leaf matter D (FMD), dry leaf matter D (DMD) obtained in a forced air oven at $60{ }^{\circ} \mathrm{C}$ for 7 days and weighed thereafter; area of leaf $\mathrm{D}$ (ALD) measured by a leaf area meter; and SPAD index using a portable chlorophyll meter.

\section{Nutrition analysis}

After washing and drying, the D leaves of the pineapple slips were ground in a Wiley mill to pass 60 mesh sieves. Then the powder was subjected to digestion by sulfur combined with hydrogen peroxide and the total $\mathrm{N}, \mathrm{P}$ and $\mathrm{K}$ contents were quantified. The Nessler method was used for N; P content was determined by molecular absorption spectrophotometry $(725 \mathrm{~nm})$ after reaction with vitamin $\mathrm{C}$ and ammonium molybdate; $\mathrm{K}$ contente was determined by flame photometry. The accumulated $\mathrm{N}, \mathrm{P}$ and $\mathrm{K}$ were calculated by multiplying the shoot dry weight with the respective nutrient content.

\section{Bacterial Count}

The bacteria on root tissue and D leaf were counted using the technique of the most probable number according to Döbereiner et al., (1995). Samples of $10 \mathrm{~g}$ of the roots and $10 \mathrm{~g}$ of $\mathrm{D}$ leaf were ground in $90 \mathrm{~mL}$ saline solution $\left(\mathrm{NaCl}, 8.5 \mathrm{~g} \mathrm{~L}^{-1}\right)$ and from this dilution $\left(10^{-1}\right)$ a serial dilution was performed by dissolving $1.0 \mathrm{~mL}$ of the 
respective previous dilution in $9.0 \mathrm{~mL}$ of saline dilution, until reaching $10^{-7}$. Aliquots of $100 \mu \mathrm{L}$ of the dilutions were transferred to glass vials containing $5.0 \mathrm{~mL}$ of semisolid JMV medium. The vials were incubated at $30{ }^{\circ} \mathrm{C}$ for 7 days. Thereafter, bacterial growth was evaluated by the presence of a white film on the medium surface. The number of bacteria was determined according to the McCrady table, for three replicates per dilution.

\section{Statistical analysis}

The results were subjected to analysis of variance and the treatment effects, for qualitative variables, were compared based on mean contrasts (Table 1), as described by Alvarez V. \& Alvarez (2006). The regression equations for quantitative variables were adjusted according to the sampling times and points of maximum acidity (lowest $\mathrm{pH}$ ) and $\mathrm{P}$ solubilization were calculated by these equations. The F test was applied to $10 \%$ significance in the analysis of the factors.

\section{RESULTS AND DISCUSSION}

\section{Selection and characterization of diazotrophic phosphate-solubilizing bacteria}

Of the 20 diazotrophic isolates evaluated, 11 are able to solubilize phosphates in vitro (Table 2). The visualization of the translucent halo and its subsequent measurement was facilitated in the medium containing $\mathrm{Ca}_{5}\left(\mathrm{PO}_{4}\right)_{3} \mathrm{OH}$ as $\mathrm{P}$ source. Halos were detected in the medium containing $\mathrm{Ca}\left(\mathrm{H}_{2} \mathrm{PO}_{4}\right)_{2}$, but not contrasted sufficiently for measurements. On the other hand, colony growth was observed in the presence of Araxá rock phosphate, but no solubilization halo after seven days of incubation. Apart from the P source, other factors such as carbon (Nautiyal, 1999; Silva Filho \& Vidor, 2000) and nitrogen sources (Nautiyal, 1999) may also interfere with the efficiency of selection of phosphate-solubilizing bacteria on solid medium. The solubilization halos of the endophytic root bacterium UENF 114111 were largest, (Table 2). This bacterium as well as UENF 117111, an endophytic isolated from leaves, were evaluated thereafter for the capacity of phosphate solubilization in liquid medium.

The presence of bacteria led to an increase of $183 \%$ of $\mathrm{P}$ content in liquid medium and a decrease of $38 \%$ in $\mathrm{pH}$, compared to the control (Table 3). The bacterium UENF 114111 increased $\mathrm{P}$ content most, both in the medium with $\mathrm{Ca}_{5}\left(\mathrm{PO}_{4}\right)_{3} \mathrm{OH}(30 \%)$ and with Araxá rock phosphate (9\%), with a similar performance in solid medium. $\mathrm{P}$ solubilization in the different media differed; the amount of soluble $\mathrm{P}$ was $267 \%$ higher in the medium with $\mathrm{P}$ source $\mathrm{Ca}_{5}\left(\mathrm{PO}_{4}\right)_{3} \mathrm{OH}$ than in the medium containing Araxá rock phosphate.

The equations adjusted for $\mathrm{pH}$ and $\mathrm{P}$ content as a function of sampling time were mostly quadratic (Table 4). These equations indicated that the acidity produced by microorganisms and $\mathrm{P}$ contents increased simultaneously, with most intense increases in the beginning, reaching a maximum and then a curvilinear

Table 1. Coefficient of contrasts

\begin{tabular}{|c|c|c|c|c|c|}
\hline \multirow{2}{*}{ Treatments } & \multicolumn{5}{|c|}{ Contrasts } \\
\hline & $\mathbf{C}_{1}$ & $\mathbf{C}_{2}$ & $\mathbf{C}_{3}$ & $\mathbf{C}_{4}$ & $\mathbf{C}_{5}$ \\
\hline \multicolumn{6}{|c|}{ Coefficient of contrasts of treatments of phosphate solubilization by diazotrophic bacteria in liquid medium and controls ${ }^{1}$} \\
\hline$(-) / \mathrm{Ca}_{5}\left(\mathrm{PO}_{4}\right)_{3} \mathrm{OH}$ & -2 & -1 & 0 & 0 & 0 \\
\hline (-) / Araxá rock phosphate & -2 & 1 & 0 & 0 & 0 \\
\hline UENF1141111/ $\mathrm{Ca}_{5}\left(\mathrm{PO}_{4}\right)_{3} \mathrm{OH}$ & 1 & 0 & -1 & -1 & 0 \\
\hline UENF1141111 / Araxá rock phosphate & 1 & 0 & 1 & 0 & -1 \\
\hline UENF1171111/ $\mathrm{Ca}_{5}\left(\mathrm{PO}_{4}\right)_{3} \mathrm{OH}$ & 1 & 0 & -1 & 1 & 0 \\
\hline UENF1171111 / Araxá rock phosphate & 1 & 0 & 1 & 0 & 1 \\
\hline
\end{tabular}

Coefficient of contrasts of bacterial inoculation treatments of pineapple slips of the cultivars Imperial and Pérola and controls ${ }^{2}$

\begin{tabular}{lrrrr}
\hline (-) Imperial & -2 & 0 & 0 & 0 \\
(-) Pérola & -2 & 0 & 0 & 0 \\
UENF114111/ Imperial & 1 & 0 & 1 & 0 \\
UENF114111/ Pérola & 1 & 1 & 0 & 0 \\
UENF117111/ Imperial & 1 & 0 & -1 & 0 \\
UENF117111/ Pérola & 1 & -1 & 0 & 0 \\
\hline
\end{tabular}

${ }^{1}$ Contrasts: $\mathrm{C}_{1}=(-)$ vs. Bacteria; $\mathrm{C}_{2}=(-) / \mathrm{Ca}_{5}\left(\mathrm{PO}_{4}\right)_{3} \mathrm{OH}$ vs. (-) / Araxá rock phosphate; $\mathrm{C}_{3}=\mathrm{Bacteria}_{2} \mathrm{Ca}_{5}\left(\mathrm{PO}_{4}\right)_{3} \mathrm{OH}$ vs. $\mathrm{Bacteria} / \mathrm{Araxá}$ rock phosphate; $\mathrm{C}_{4}=\mathrm{UENF} 114111 / \mathrm{Ca}_{5}\left(\mathrm{PO}_{4}\right)_{3} \mathrm{OH}$ vs. UENF117111 / $\mathrm{Ca}_{5}\left(\mathrm{PO}_{4}\right)_{3} \mathrm{OH} ; \mathrm{C}_{5}=\mathrm{UENF} 114111 /$ Araxá rock phosphate vs. UENF117111 / Araxá rock phosphate.

${ }^{2}$ Contrasts: $\mathrm{C}_{1}$, (-) vs. Bacteria; $\mathrm{C}_{2}$, UENF117111 / Pérola vs. UENF114111 / Pérola; $\mathrm{C}_{3}$, UENF117111 / Imperial vs. UENF114111 / Imperial; $\mathrm{C}_{4}$, UENF114111 / Imperial vs. UENF114111 / Pérola; $\mathrm{C}_{5}$, UENF117111 / Imperial vs. UENF117111 / Pérola. 
decrease. The points of maximum $\mathrm{P}$ solubilization and minimum $\mathrm{pH}$ were between the fourth and fifth day after inoculation. The $\mathrm{pH}$ decrease and $\mathrm{P}$ solubilization increase rates were higher for bacterium UENF 117111, for both $\mathrm{P}$ sources. The ability of microbes to solubilize phosphates has been attributed to $\mathrm{pH}$ reduction (Rodriguez \& Fraga, 1999; Pérez et al., 2007). The release of organic ligands, complexing agents, extracellular polymers, inorganic acids, protons during the assimilation of $\mathrm{NH}_{4}^{+}$, and of other cations are also mechanisms that can be involved in the process of phosphate solubilization by microorganisms (Rodriguez \& Fraga 1999). In all treatments, the bacteria grown in liquid medium reached the stationary phase after less than $72 \mathrm{~h}$ of growth (Figure 1).

Table 2. Identification of diazotrophic phosphate-solubilizing bacteria in solid medium containing different $\mathrm{P}$ sources

\begin{tabular}{|c|c|c|c|}
\hline \multirow{2}{*}{$\begin{array}{l}\text { Strain code in the UENF } \\
\text { culture collection }{ }^{1}\end{array}$} & \multicolumn{3}{|c|}{$P$ sources } \\
\hline & $\begin{array}{c}\mathrm{Ca}_{5}\left(\mathrm{PO}_{4}\right)_{3} \mathrm{OH}^{2} \\
(\mathrm{~mm})\end{array}$ & $\mathrm{Ca}\left(\mathrm{H}_{2} \mathrm{PO}_{4}\right)_{2}{ }^{3}$ & Araxá rock phosphate ${ }^{4}$ \\
\hline Pseudomonas sp. (P07) & $6.90 \pm 0.32$ & + & + \\
\hline UENF 111111 & $6.31 \pm 0.39$ & + & + \\
\hline UENF 111221a & $5.41 \pm 0.51$ & + & + \\
\hline UENF $111221 b$ & - & - & - \\
\hline UENF 111222 & - & - & - \\
\hline UENF 112531 & - & - & - \\
\hline UENF 114111 & $7.63 \pm 0.81$ & + & + \\
\hline UENF 114112 & $7.28 \pm 1.40$ & + & + \\
\hline UENF 114121 & $6.94 \pm 1.46$ & + & + \\
\hline UENF 114131 & $5.87 \pm 0.31$ & + & + \\
\hline UENF 114132 & $6.48 \pm 1.50$ & + & + \\
\hline UENF 114511 & $2.68 \pm 0.11$ & + & + \\
\hline UENF 117111 & $5.17 \pm 0.45$ & + & + \\
\hline UENF 117221 & - & - & - \\
\hline UENF 117222a & - & - & - \\
\hline UENF $117222 b$ & - & - & - \\
\hline UENF 118501a & - & - & - \\
\hline UENF $118501 \mathrm{~b}$ & - & - & - \\
\hline UENF 118502 & - & - & - \\
\hline UENF 118503a & - & - & - \\
\hline UENF $118503 b$ & $5.41 \pm 0.51$ & + & + \\
\hline
\end{tabular}

${ }^{1}$ Strain code in the UENF culture collection: designation UENF, followed by six digits that indicate the crop (1: pineapple); cultivar (1: Smooth Cayenne); plant tissue (1: rhizosphere, 2: root / epiphytic, 3, 4: root / endophytic, 7: leaf / endophytic, 8: stem / epiphytic); culture medium (1: JMV, 2: JNFb, 5: NFb); dilution; number of order in the isolate collection.

${ }^{2}$ Halo diameter $(\mathrm{mm})$ : calculated as $=$ total diameter - colony diameter. The experimental means of the three replicates include the standard error.

3 +: detected colony growth and halo formation, but not visible enough for measurements.

${ }^{4}+$ : colony growth detected, though without halo formation. -: no colony growth detected.

Table 3. Mean contrasts and relative increment in the means of the compared groups (in brackets) of the test of phosphate solubilization by diazotrophic bacteria in liquid medium

\begin{tabular}{|c|c|c|c|}
\hline \multirow{2}{*}{ F.V. ${ }^{1}$} & \multirow{2}{*}{ G.L. } & \multicolumn{2}{|c|}{ Mean contrasts (relative increment ${ }^{1}$ ) } \\
\hline & & $\mathrm{pH}$ & $\mathbf{P}\left(\mathrm{mg} \mathrm{L}^{-1}\right)$ \\
\hline (-) vs. Bacteria & 1 & $-1.78 * * \quad(38)$ & $10.59 * *(183)$ \\
\hline$(-) / \mathrm{Ca}_{5}\left(\mathrm{PO}_{4}\right)_{3} \mathrm{OH}$ vs. (-)/ Araxá rock phosphate & 1 & 0.00 & $-6.62 * *(267)$ \\
\hline Bacteria/ $\mathrm{Ca}_{5}\left(\mathrm{PO}_{4}\right)_{3} \mathrm{OH}$ vs. Bacteria/ Araxá rock phosphate & 1 & $-0.71 * * \quad(16)$ & $-14.52 * *(159)$ \\
\hline UENF114111 vs. UENF117111/ $\mathrm{Ca}_{5}\left(\mathrm{PO}_{4}\right)_{3} \mathrm{OH}$ & 1 & $-0.15 * *$ & $6.09 * * \quad(30)$ \\
\hline UENF114111 vs. UENF117111/ Araxá rock phosphate & 1 & $-0.13 * *$ & $0.76 * * \quad(9)$ \\
\hline Residue & 72 & 0.09 & 8.93 \\
\hline $\mathrm{CV}(\%)$ & & 5.51 & 23.25 \\
\hline
\end{tabular}

${ }^{1}$ Relative increment: $100(\mathrm{x}-\mathrm{y}) / \mathrm{y}$, where $\mathrm{x}$ is the treatment mean with the highest and $\mathrm{y}$ the treatment mean with the lowest value. $* *=$ significant by the test $\mathrm{F}$ a $1 \%$ probability.

Rev. Ceres, Viçosa, v. 61, n.3, p. 414-423, mai/jun, 2014 
The characterization in solid DYGS medium (Perin, 2002) showed circular shape, entire margin and smooth surface of both selected bacteria colonies. The UENF114111 culture was yellowish-white, diameter of 2 $-3 \mathrm{~mm}$ and absence of mucus, whereas the UENF117111 colony was white, punctate, with little mucus. On solid
JMV medium, both colonies were circular, with entire margin, smooth surface and little presence of mucus. The UENF114111 colonies were white in the center and milky on the edge. UENF117111 was yellow in the center and milky on the edge, with an average colony diameter of $2 \mathrm{~mm}$.

Table 4. Regression equation and values of maximum $\left(\mathrm{w}_{\mathrm{MAX}}\right), \mathrm{P}$ solubilization and acidity as a function of time, in treatments with and without diazotrophic bacteria inoculation (controls)

\begin{tabular}{|c|c|c|c|c|}
\hline Features & $\hat{\mathrm{Y}}$ & Regression equation & $\mathbf{w}_{\text {MAX }}$ & $\mathbf{R}^{2}$ \\
\hline$(-) / \mathrm{Ca}_{5}\left(\mathrm{PO}_{4}\right)_{3} \mathrm{OH}$ & & $\widehat{y}=\bar{y}=6.5$ & & \\
\hline$(-) /$ Rock phosphate & & $\widehat{y}=\bar{y}=6.5$ & & \\
\hline UENF114111/Ca $5\left(\mathrm{PO}_{4}\right)_{3} \mathrm{OH}$ & $\mathrm{pH}$ & $\widehat{y}=7.8-1.34^{* *} x+0.14^{* * *} x^{2}$ & 4.79 & 0.87 \\
\hline UENF114111Rock phosphate & & $\widehat{y}=7.73-1.82^{* *} x+0.20^{* *} x^{2}$ & 4.56 & 0.96 \\
\hline UENF117111/ $/ \mathrm{Ca}_{5}\left(\mathrm{PO}_{4}\right)_{3} \mathrm{OH}$ & & $\widehat{y}=7.92-1.49^{* *} x+0.15^{* *} x^{2}$ & 4.97 & 0.93 \\
\hline UENF117111/Rock phosphate & & $\hat{y}=7.70-1.99^{* *} x+0.24^{* *} x^{2}$ & 4.15 & 0.83 \\
\hline$(-) / \mathrm{Ca}_{5}\left(\mathrm{PO}_{4}\right)_{3} \mathrm{OH}$ & & $\widehat{y}=\bar{y}=9.10$ & & \\
\hline (-)/Rock phosphate & & $\widehat{y}=\bar{y}=2.48$ & & \\
\hline UENF114111/Ca ${ }_{5}\left(\mathrm{PO}_{4}\right)_{3} \mathrm{OH}$ & & $\widehat{y}=2.78+5.09^{* *} x$ & 5.00 & 0.97 \\
\hline UENF114111/Rock phosphate & $\mathrm{P}$ & $\widehat{y}=0.37+2.39^{* *} x$ & 5.00 & 0.84 \\
\hline UENF117111/Ca ${ }_{5}\left(\mathrm{PO}_{4}\right)_{3} \mathrm{OH}$ & & $\hat{y}=-10.17+19.57^{* *} x-2.09^{* *} x^{2}$ & 4.68 & 0.95 \\
\hline UENF117111/Rock phosphate & & $\widehat{\mathrm{y}}=-2.06+5.77 * \mathrm{x}-0.56{ }^{*} \mathrm{x}^{2}$ & 5.00 & 0.74 \\
\hline
\end{tabular}

${ }^{* *},{ }^{*}=$ significant by the test $\mathrm{F}$ at 1 and $5 \%$ probability, respectively
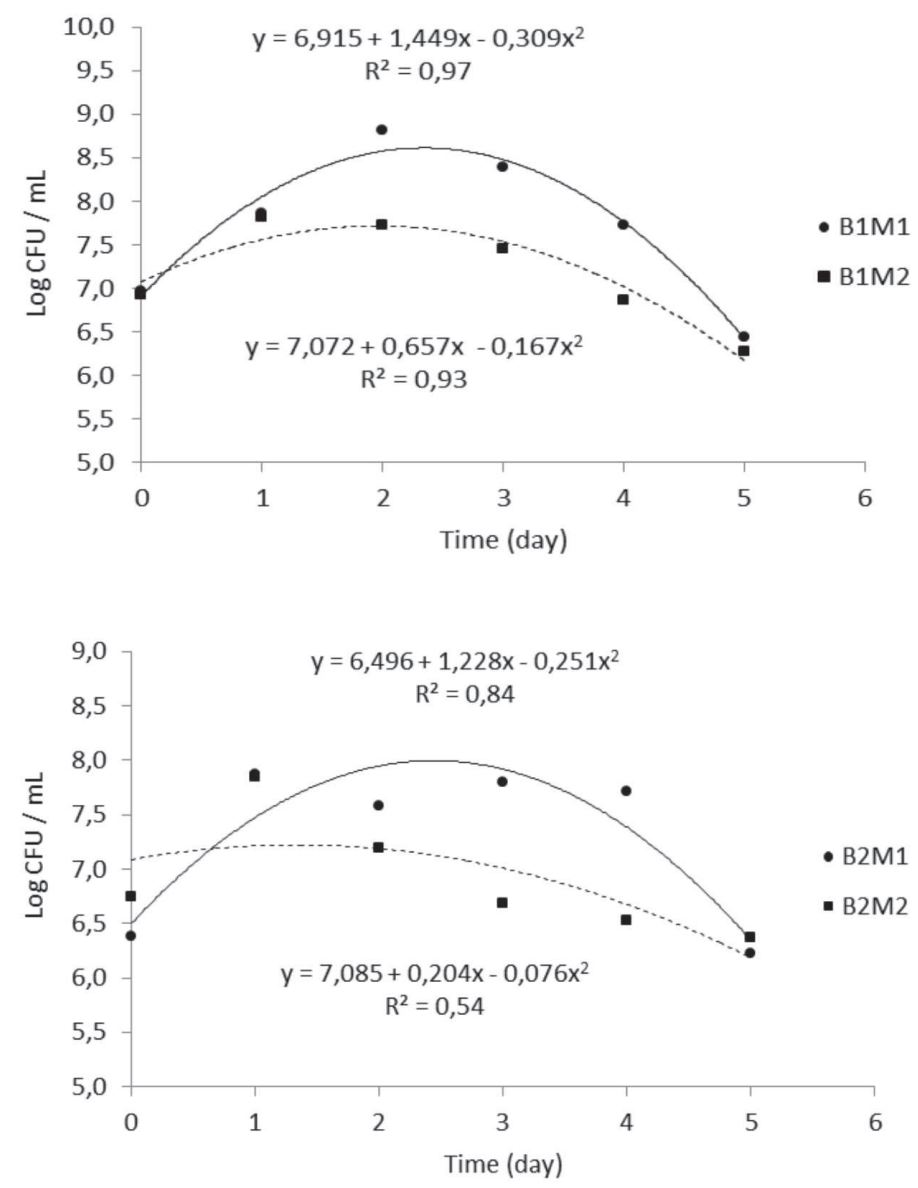

Figure 1. Growth of diazotrophic bacteria in liquid culture medium containing different phosphate sources. Abbreviations: B1, bacteria UENF114111; B2, bacteria UENF 117111; M1, medium containing $\mathrm{Ca}_{5}\left(\mathrm{PO}_{4}\right)_{3} \mathrm{OH} ; \mathrm{M} 2$, medium containing Araxá rock phosphate. 
The analysis of the partial sequence of gene 16S rDNA of the bacterial isolates selected by the program BLAST compared with the sequences contained in the database NCBI showed that both bacteria were identified with the genus Burkholderia. Data on the bacterial isolate UENF114111 were: NCBI entry number EF139184.1; Description Burkholderia sp. TNe-862 16S ribosomal RNA gene, partial sequence; $\mathrm{E}$ value 0.0; Maximum identity 98\%. Data on the Bacterial isolate UENF 117111 were: NCBI entry number AY965240.1; Description Burkholderia silvatlantica isolate SRMrh20 16S ribosomal RNA gene, partial sequence; E value 0.0; Maximum identity $99 \%$.

Burkholderia were isolated from more than 30 species of cultivated plants (Compant et al., 2008). The ability of solubilizing calcium phosphate of the strains tested may be due to the acid metabolism of gluconic acid, observed by Lin et al., (2006) in Burkholderia cepacia. In gram-negative bacteria, gluconic acid is produced by direct glucose oxidation in the periplasmatic space (Goldstein, 1996). Consequently, the organic acids diffuse into the extracellular medium and solubilize $\mathrm{P}$ from mineral phosphates since these acids release protons and anions that complex metals such as calcium (Gadd, 1999).

\section{Interaction between phosphate-solubilizing diazotrophs and pineapple}

Once the diazotrophic strains able to solubilize phosphates in vitro were selected and characterized, 'Imperial' and 'Pérola' pineapple slips were tested in situ to verify the response to bacterial inoculation along with Araxá rock phosphate application in promoting growth and development.

The mean contrasts (Table 1) were calculated from the averages shown in Table 5. The mean contrasts represent the real magnitude of the difference between the compared treatment means of the characteristics of growth and nutrient content of pineapple slips. Significant differences were observed in the initial pineapple development with the inoculation of diazotrophic, phosphate-solubilizing bacteria (Table 5). The contrast that compared the D leaf length (LLD) of the controls and the other treatments (control versus bacteria) showed an average increase of $12.2 \mathrm{~cm}$. This corresponds to a gain of $71 \%$ of inoculated over uninoculated treatments. The inoculation of diazotrophic, phosphate solubilizing bacteria combined with Araxá phosphate resulted in increments in all growth characteristics of pineapple shoots, for example, an increase of $173 \%$ in dry matter of D leaf and $179 \%$ in area of D leaf (Table 5). Increases in the nutrient accumulation of D leaf of 148, 220 and $143 \%$ of N, P, K, respectively, were observed (Table 6). 
Table 6. Mean contrasts, relative increment, residual mean square (RMS) and coefficient of variation (CV) for the characteristics of growth of the above-ground part and leaf nutrient accumulation in 'Imperial' and 'Pérola' pineapple slips inoculated with diazotrophic phosphate-solubilizing bacteria combined with Araxá rock phosphate application

\begin{tabular}{|c|c|c|c|c|c|c|c|c|c|c|c|c|c|c|}
\hline \multirow{4}{*}{ S.V. } & \multirow{4}{*}{ D.F. } & \multicolumn{13}{|c|}{ Mean contrasts (relative increment ${ }^{1}$ ) } \\
\hline & & \multicolumn{10}{|c|}{ Aboveground part ${ }^{2}$} & \multicolumn{3}{|c|}{ Nutrient content } \\
\hline & & $\mathbf{L N}$ & PH & LLD & WLD & \multirow{2}{*}{$\begin{array}{l}\text { SD } \\
\mathbf{m m}\end{array}$} & \multirow{2}{*}{$\begin{array}{l}\text { RD } \\
\text { cm }\end{array}$} & FMD & DMD & \multirow{2}{*}{$\begin{array}{l}\text { ALD } \\
\mathbf{c m}^{2} \\
\end{array}$} & \multirow[t]{2}{*}{ SPAD } & $\mathbf{N}$ & $\mathbf{P}$ & $\mathbf{K}$ \\
\hline & & & & $\mathbf{c m}$ & & & & & & & & \multicolumn{3}{|c|}{ mg / leaf D } \\
\hline (-) vs. Bacteria & 1 & $\begin{array}{l}8.0^{* *} \\
(67)\end{array}$ & $\begin{array}{c}11.4^{* *} \\
(84)\end{array}$ & $\begin{array}{c}12.2 * * \\
(71)\end{array}$ & $\begin{array}{c}0.79 * * \\
(43)\end{array}$ & $\begin{array}{c}8.82 * * \\
(62)\end{array}$ & $\begin{array}{c}14.9 * * \\
(53)\end{array}$ & $\begin{array}{c}3.80 * * \\
(223)\end{array}$ & $\begin{array}{c}0.45^{* * *} \\
(173)\end{array}$ & $\begin{array}{c}33.90 * * \\
(179)\end{array}$ & $\begin{array}{c}3.74 * \\
(9)\end{array}$ & $\begin{array}{c}3.96 * * \\
(148)\end{array}$ & $\begin{array}{c}0.56 * * \\
(220)\end{array}$ & $\begin{array}{c}9.41 * * \\
(143)\end{array}$ \\
\hline 117111 vs. 114111 / Pérola & 1 & $\begin{array}{c}-1.4^{* *} \\
(7)\end{array}$ & $\begin{array}{c}1.8^{* *} \\
(7)\end{array}$ & $\begin{array}{l}5.2 * \\
(19)\end{array}$ & $\begin{array}{l}0.38 \\
(16)\end{array}$ & $\begin{array}{c}0.67 * * \\
(3)\end{array}$ & $\begin{array}{l}-4.4^{\circ} \\
(11)\end{array}$ & $\begin{array}{c}1.69 * * \\
(34)\end{array}$ & $\begin{array}{c}0.20^{*} \\
(30)\end{array}$ & $\begin{array}{c}30.11 * * \\
(83)\end{array}$ & $\begin{array}{c}1.64 * * \\
(3)\end{array}$ & $\begin{array}{l}1.90^{\circ} \\
(32)\end{array}$ & $\begin{array}{l}0.10^{\circ} \\
(14)\end{array}$ & $\begin{array}{c}4.75^{*} \\
(35)\end{array}$ \\
\hline 117111 vs. 114111 / Imperial & 1 & $\begin{array}{l}1.4 \\
(8)\end{array}$ & $\begin{array}{l}4.7 * \\
(22)\end{array}$ & $\begin{array}{l}3.4^{\circ} \\
(13)\end{array}$ & $\begin{array}{c}-0.10^{*} \\
(2)\end{array}$ & $\begin{array}{c}0.90 \\
(4)\end{array}$ & $\begin{array}{l}4.4^{*} \\
(11)\end{array}$ & $\begin{array}{c}1.40 * \\
(29)\end{array}$ & $\begin{array}{l}0.20^{\circ} \\
(27)\end{array}$ & $\begin{array}{c}15.70^{*} \\
(34)\end{array}$ & $\begin{array}{c}-0.90^{\circ} \\
(2)\end{array}$ & $\begin{array}{c}0.00 \\
(0)\end{array}$ & $\begin{array}{c}0.20 * \\
(30)\end{array}$ & $\begin{array}{c}1.20^{\circ} \\
(8)\end{array}$ \\
\hline Imperial vs. Pérola / UENF114111 & 1 & $\begin{array}{l}2.0^{\circ} \\
(10)\end{array}$ & $\begin{array}{c}0.2^{* *} \\
(1)\end{array}$ & $\begin{array}{c}2.4 * * \\
(8)\end{array}$ & $\begin{array}{c}0.06^{*} \\
(2)\end{array}$ & $\begin{array}{c}4.00^{*} \\
(19)\end{array}$ & $\begin{array}{l}-5.6^{\circ} \\
(14)\end{array}$ & $\begin{array}{c}0.61 * * \\
(10)\end{array}$ & $\begin{array}{c}0.09 * * \\
(12)\end{array}$ & $\begin{array}{c}4.14 * * \\
\text { (7) }\end{array}$ & $\begin{array}{c}9.94 * \\
(25)\end{array}$ & $\begin{array}{c}1.33^{*} \\
(20)\end{array}$ & $\begin{array}{c}-0.10^{*} \\
(12)\end{array}$ & $\begin{array}{c}1.56^{* * *} \\
(9)\end{array}$ \\
\hline Imperial vs. Pérola / UENF117111 & 1 & $\begin{array}{r}4.8 \\
(27)\end{array}$ & $\begin{array}{l}3.1 \\
(2)\end{array}$ & $\begin{array}{l}0.6 \\
(2)\end{array}$ & $\begin{array}{c}-0.38 \\
(16)\end{array}$ & $\begin{array}{l}4.20^{\circ} \\
(20)\end{array}$ & $\begin{array}{c}3.2^{\circ} \\
(8)\end{array}$ & $\begin{array}{c}0.27 \\
(6)\end{array}$ & $\begin{array}{c}0.05 \\
(9)\end{array}$ & $\begin{array}{c}-10.30 \\
(28)\end{array}$ & $\begin{array}{c}7.44^{\circ} \\
(18)\end{array}$ & $\begin{array}{c}-0.59 \\
(10)\end{array}$ & $\begin{array}{c}0.01 \\
(2)\end{array}$ & $\begin{array}{c}-1.97 \\
(15)\end{array}$ \\
\hline RMS & 24 & 8.3 & 19.2 & 32.5 & 0.19 & 22.50 & 56.48 & 2.20 & 0.04 & 252.86 & 19.56 & 5.22 & 0.07 & 20.94 \\
\hline $\mathrm{CV}(\%)$ & & 16.6 & 20.7 & 22.5 & 18.55 & 23.61 & 19.87 & 35.40 & 35.59 & 38.33 & 10.51 & 43.04 & 42.57 & 35.60 \\
\hline
\end{tabular}

${ }^{1}$ Relative increment: $100(\mathrm{x}-\mathrm{y}) / \mathrm{y}$, where $\mathrm{x}$ is the mean of the treatment with the highest and $\mathrm{y}$ the mean of the treatment with the lowest value.

${ }^{2}$ Aboveground part: LN, leaf number; PH, plant height; LLD, D leaf length; WLD, D leaf width; SD, stem diameter; RD, rosette diameter; FMD, D leaf fresh matter; DMD, D leaf dry matter; ALD, area of leaf D; SPAD, chlorophyll content.

$* *, *$ and ${ }^{\circ}=$ significant by the $\mathrm{F}$ test at 1,5 and $10 \%$ probability, respectively 
The improvement in the initial development of 'Imperial' and 'Pérola' pineapple slips inoculated with Burkholderia might not be only due to the processes of biological nitrogen fixation and Araxá phosphate solubilization, but also to the synthesis of phytohormones and increased host plant resistance to biotic and abiotic stresses (Compant et al., 2008). In vitro, both strains can synthesize indole and act antagonistically against the phytopathogenic fungus Fusarium subglutinans f. sp. ananas (Baldotto et al., 2010).

Natural phosphates, such as Araxá rock phosphate are poorly soluble in water. Therefore microbiota management strategies to increase their solubility in the cultivation environments are being sought. Another still unexplored possibility is the use of these bacteria in bioreactors for production of soluble fertilizers derived from phosphate rocks. Some genes involved in the solubilization of phosphate minerals have been isolated and inserted into plant growth-promoting bacteria (Rodriguez et al., 2006), representing a promising prospect of enhancing the efficiency of the bacteria used as inoculants and in bio-fertilizer formulations.

Among the bacteria studied, the strain UENF114111 (Burkholderia sp.) increased $\mathrm{P}$ content most in both pineapple cultivars, confirming better phosphate solubilization capacity in vitro (Tables 2 and 3 ) as well as in situ (Tables 5 and 6) than that of UENF117111 bacterium (Burkholderia silvatlantica). In general, the response of cultivar Pérola to inoculation was higher, for both bacterial strains, resulting in higher rates of growth and nutrient accumulation than those of cultivar Imperial (Tables 5 and 6).

The bacterial recovery rates in the different treatments are shown in Table 5. One effect of inoculation was an increase of diazotrophic population in the D leaf and roots of pineapple slips. The population data show the capacity of the bacteria to persist after 150 days of inoculation and suggest the use of the diazotrophic, phosphate-solubilizing bacteria Burkholderia to promote the early development of pineapple plantlets, which may represent an important possibility of reducing production costs in view of the effects of enhanced nutritional efficiency and growth.

\section{CONCLUSIONS}

The inoculation of Burkholderia promotes the increase in $\mathrm{N}, \mathrm{P}$ and $\mathrm{K}$ content in pineapple leaf.

The bacterial strain Burkholderia sp. (UENF114111) proved most effective in promoting growth and leaf nutrient accumulation of 'Imperial' and 'Pérola' pineapple slips.

'Pérola' pineapple was more responsive to Burkholderia inoculation than 'Imperial'.

\section{ACKNOWLEDGEMENTS}

The authors are grateful to the researcher Alexandre Catellan (EMBRAPA Soja) for providing the bacterium Pseudomonas sp. (P07), to Pedro Henrique Monnerat (UENF) for his participation in the nutrient analysis and to Lúcia Helena Boddey and Erineudo de Lima Canuto for their assistance with the bacterial counts. They also wish to thank Conselho Nacional de Desenvolvimento Científico e Tecnológico (CNPq), Fundação de Amparo à Pesquisa do Estado do Rio de Janeiro (FAPERJ) and Fundação do Amparo à Pesquisa do Estado de Minas Gerais (FAPEMIG) for financial support.

\section{REFERENCES}

Alvarez V VH \& Alvarez GAM (2006) Comparações de médias ou testes de hipóteses? Contrastes! Boletim Informativo da Sociedade Brasileira de Ciência do Solo, 31:24-34.

Baldotto LEB \& Olivares FL (2008) Phylloepiphytic interaction between bacteria and different plant species in a tropical agricultural system. Canadian Journal of Microbiology, 54:918931.

Baldotto LEB, Baldotto MA, Olivares FL, Viana AP \& BressanSmith R (2010) Seleção de bactérias promotoras de crescimento no abacaxizeiro (Ananas comosus L. Merril) cultivar Vitória durante a aclimatização. Revista Brasileira de Ciência do Solo, 34:349-360.

Cattelan AJ, Hartel PG \& Fuhrmann JJ (1999) Screening for plant growth-promoting rhizobacteria to promote early soybean growth. Soil Science Society American Journal, 63:1670-1680.

Compant S, Nowak J, Coenye T, Clément C \& Barka EA (2008) Diversity occurrence of Burkholderia spp. in the natural environment. FEMS Microbiology Review, 32:607-627.

Döbereiner J \& Ruschel AP (1958) Uma nova espécie de Beijerinckia. Revista de Biologia, 1:261-272.

Döbereiner J, Baldani VLD \& Baldani JI (1995) Como isolar e identificar bactérias diazotróficas de plantas não-leguminosas. Brasília, EMBRAPA-SPI. 60p.

Embrapa - Empresa Brasileira de Pesquisa Agropecuária (1980) Centro Nacional de Levantamento e Classificação de Solos. I Reunião de Classificação e Correlação de Solos. Rio de Janeiro, Embrapa Produção de Informação. 208p. (Boletim Técnico, $62)$.

Ewing B \& Green P (1998) Base-calling of automated sequencer traces using phred. II. Error probabilities. Genome Research, 8:186-194.

Ewing B, Hillier L, Wendl MC \& Green P (1998) Base-calling of automated sequencer traces using phred. I. Accuracy assessment. Genome Research, 8:175-185.

Gadd GM (1999) Fungal production of citric and oxalic acid: importance in metal speciation physiology, biogeochemical processes. Advanced Microbial Physiology, 41:47-92.

Goldstein AH (1996) Involvement of the quinoprotein glucose dehydrogenase in the solubilization of exogenous phosphates by Gram-negative bacteria. In: Torriani-Gorini A, Yagil E \& Silver S (Eds.) Phosphate in Microorganisms: Celular and Molecular Biology. Washington, ASM Press DC. p.197-203.

Gordon D, Abajian C \& Green P (1998) Consed: a geographical tool for sequence finishing. Genome Research, 8:195-202. 
Halmann J, Quadt-Hallmann A, Mahaffee WF \& Kloepper JW (1997) Bacterial endophytes in agricultural crops. Canadian Journal of Microbiology, 43:895-914.

Lin TF, Huang HI, Shen FT \& Young CC (2006) The protons of gluconic acid are the major factor responsible for the dissolution of tricalcium phosphate by Burkholderia cepacia CC-A174. Bioresource Technology, 97:957-960.

Nautiyal CS (1999) An efficient microbiological growth medium for screening phosphate solubilizing microorganisms. FEMS Microbiology Letters, 170:265-270.

NCBI (2009) Blast database. Disponível em: <http:// www.ncbi.nlm.nih.gov/BLAST/>. Acessado em: 20 de agosto de 2009.

Pérez E, Sulbarán M, Ball MM \& Yarzábal A (2007) Isolation and characterization of mineral phosphate-solubilizing bacteria naturally colonizing a limonitic crust in the south-eastern Venezuelan region. Soil Biology Biochemistry, 39:2905-2914.

Perin L (2002) Ecologia e diversidade de Glucanocetobacter diazotrophicus associada à cana-de-açúcar (Saccharum spp.). Dissertação de Mestrado. Universidade Federal Rural do Rio de Janeiro, Seropédica. 40p.

Pikovskaya RI (1948) Mobilization of phosphorus in soil in connection with the vital activity of some microbial species. Mikrobiologiya, 17:362-370.

Rodriguez H \& Fraga R (1999) Phosphate solubilizing bacteria and their role in plant growth promotion. Biotechnology Advances, 17:319-339.

Rodriguez H, Fraga R, Gonzalez T \& Bashan Y (2006) Genetics of phosphate solubilization and its potential applications for improving plant growth-promoting bacteria. Plant and Soil, 287:15-21
Santos ST (2008) Biogeografia de bactérias culturáveis associadas às fruteiras tropicais. Dissertação de Mestrado. Universidade Estadual do Norte Fluminense Darcy Ribeiro, Campos dos Goytacazes. 92p.

Silva Filho GN \& Vidor C (2000) Solubilização de fosfatos por microrganismos na presença de fontes de carbono. Revista Brasileira de Ciência do Solo, 24:311-319.

Tapia-Hernández A, Bustillos-Cristales MR, Jiménez-Salgado T, Caballero-Mellado J \& Fuentes-Ramírez LE (2000) Natural endophytic occurrence of Acetobacter diazotrophicus in pineapple plants. Microbial Ecology, 39:49-555.

Verma SC, Ladha JK \& Tripathi AK (2001) Evaluation of plant growth promoting and colonization ability of endophytic diazotrophs from deep water rice. Journal Biotechnology, 91:127-141.

Weber OB, Correia D, Silveira MR, Crisóstomo LA, Oliveira EM \& Sá EG (2003) Efeito da bactéria diazotrófica em mudas micropropagadas de abacaxizeiro Cayenne Champac em diferentes substratos. Pesquisa Agropecuária Brasileira, 38:689-696.

Weber OB, Baldani VLD, Teixeira KRS, Kirchhof G, Baldani JI \& Döbereiner J (1999) Isolation and characterization of diazotrophic bacteria from banana and pineapple plants. Plant Soil, 210:103-113.

Weber OB, Lima RN, Crisótomo LA, Freitas JAD, Carvalho ACPP \& Maisa AHNM (2010) Effect of diazotrophic bacterium inoculation and organic fertilization on yield of Champaka pineapple intercropped with irrigated sapota. Plant Soil, 327:355-364.

Weisburg WG, Barns SM, Pelletier DA \& Gene-Trak DJL (1991) $16 \mathrm{~S}$ ribossomal DNA amplification for phylogenetic study. Journal Bacteriology, 173:697-703. 